Article

\title{
Effect of Irrigation Schemes on Forage Yield, Water Use Efficiency, and Nutrients in Artificial Grassland under Arid Conditions
}

\author{
Yuhong Tian *, Yiqing Liu and Jianjun Jin \\ State Key Laboratory of Earth Surface Processes and Resource Ecology, School of Natural Resources, \\ Faculty of Geographical Science, Beijing Normal University, Beijing 100875, China; \\ 201521190006@mail.bnu.edu.cn (Y.L.); jjjin@bnu.edu.cn (J.J.) \\ * Correspondence: tianyuhong@bnu.edu.cn; Tel.: +86-10-5880-0198
}

Received: 22 September 2017; Accepted: 2 November 2017; Published: 6 November 2017

\begin{abstract}
Artificial grasslands are effective solutions to problems with grassland degradation. Water scarcity is an important limitation for grassland production in arid regions. In this study, we carried out comparison experiments to assess the impacts of irrigation schemes on forage yield, water use efficiency, and nutrients in the single and mixed sowing ways of Medicago sativa L. and Agropyron cristatum in different stages in artificial grassland. Results indicated that deficit irrigation can increase forage yields of $M$. sativa and A. cristatum in most growth stages and sowing treatments. Heavy deficit irrigation or even no irrigation had the greatest potential to increase forage yields of both species in the squaring stage and instantaneous water-use efficiency (WUEI) in all growth stages. They can also significantly increase the nutritional level of $M$. sativa using a mixed sowing method. In June and September, only irrigating to near field capacity (T1) can increase the long-term water-use efficiency (WUEL) of both species. We suggest irrigating with water to near field capacity in June, and applying deficit irrigation in July and August. Deficit irrigation is an effective water management technique to both save water and increase forage quality in arid areas.
\end{abstract}

Keywords: yield; water-use efficiency; nutrient elements; deficit irrigation

\section{Introduction}

Grasslands are an important ecosystem in the world and have great potential for carbon sequestration and other ecological functions [1]. However, as a result of widespread overgrazing and climate change, large areas of grasslands have experienced degradation, which has led to water loss and soil erosion, soil salinization, and reduction of grassland production and forage quality. The problems have combined to greatly damage the ecosystems and inhibit the development of animal husbandry. Artificial grasslands are an effective way to address the problems created by grassland degradation [2]. Artificial grasslands can supply a large quantity of high quality forage grasses, requiring less land than natural grasslands, relieving high grazing pressure, and promoting recovery of degraded natural grasslands [3].

Water scarcity is an important limitation for forage growth in grasslands in arid regions [4,5]. Studies have shown that irrigated grasslands may have higher and more stable rates of yield [6-8]. However, achieving high output yields with less irrigation in an efficient and sustainable manner is one of the key challenges in artificial grasslands in arid areas. Deficit irrigation is irrigating with limited water to obtain maximum water use efficiency and stable yields instead of obtaining maximum yields. It is believed to increase the net income of farms [9] (pp. 57-66) because of the reduced cost of irrigation and increased irrigation efficiency [10]. One effective way to solve water scarcity problems is 
by optimizing plant water usage through enhancing yield, water use efficiency, and nutritional levels by applying deficit irrigation [11].

Forage nutrients such as crude protein, cellulose, and crush ash are indicators to assess forage quality and verify the effectiveness of irrigation in artificial grassland [12]. Changes of nutrient contents were consistent with vegetation stages and management measures such as irrigation [13]. Forages with high crude protein usually have high nutrient levels and have been verified to increase maximal milk and protein production of dairy cows when the content of crude protein is no more than $16.5 \%$ [14]. Forage in a given growth phases has different dry-matter digestibility, which were proven to be closely associated with changes in yield and the digestibility of the cellulose [15]. Ash content could be used to assess the mineral content level because it may vary considerably among species under different management measures even when the nutrition and climate are identical [16].

Current studies have explored the influence of deficit irrigation on yield and the quality of crops [17-19]. Lu et al. [20] assessed the influence of drip irrigation by reclaimed water on tomato yield and quality. Audrey et al. [21] analyzed the functional response of leaf- and plant-hoppers to modern fertilization and irrigation of hay meadows. However, few studies have discussed the effects of deficit irrigation on forage yield, water use efficiency, and nutrients in artificial grasslands in arid areas.

Using single and mixed sowing treatments of Agropyron cristatum and Medicago sativa L., this study compared forage yield, water use efficiency, and nutrients under different irrigation conditions. The study was designed to provide useful information for alleviating water shortages and promoting sustainable development of artificial grasslands by both increasing plant production and optimizing water use efficiency in arid areas.

\section{Materials and Methods}

\subsection{Study Area}

The study area is located in Maodeng Ranch in eastern Xilinhot, Inner Mongolia. Maodeng Ranch is the ecological experimental station of Inner Mongolia University. The area belongs to a meadow steppe-typical steppe area. As the hinterland of the Inner Mongolia Xilingol League Prairie, Xilinhot is located in the central Inner Mongolia Autonomous Region $\left(43^{\circ} 02^{\prime}-44^{\circ} 52^{\prime} \mathrm{N}, 115^{\circ} 13^{\prime}-117^{\circ} 06^{\prime} \mathrm{W}\right)$. The region is characterized by a temperate arid continental monsoon climate. It experiences a cold and dry Siberian high winter and a warm and humid summer affected by monsoons. Annual average precipitation and temperature are $300 \mathrm{~mm}$ and $1.7^{\circ} \mathrm{C}$, respectively. Precipitation is concentrated in June to September. The average wind speed is $3.5 \mathrm{~m} / \mathrm{s}$ [22]. The soil is fertile, mainly chestnut soil. The main grassland types are temperate steppe with some lowland steppe grasslands. Edificators are Stipa grandis and Leymus chinensis. The dominant plant species are A. cristatum and Cleistogenes squarrosa. Common species are Artemisia frigida Willd., onion plants, etc.

A short growing season due to the long winter, short summer, and irregular precipitation throughout the year results in low and unstable grass production in the study area. Furthermore, overgrazing and unreasonable utilization means that large tracts of grasslands in the region are threatened by degradation, desertification, and reduced palatability. Therefore, artificial grassland construction through manual planting and management is necessary to alleviate pressure on local grasslands. At the same time, due to low precipitation and the scarcity of water resources, irrigation is important for artificial grasslands.

\subsection{Experimental Design}

The experimental plots were ploughed on 12 May 2012 and sowed on 9 June 2012. Sowing treatments included single species sowing of A. cristatum and $M$. sativa, respectively, and the mixed species sowing of the two species. The plots were planted one by one with $0.5 \mathrm{~m}$ ridges around and $1 \mathrm{~m}$ spacing between ridges. Totally 48 plots were ploughed with three replicates for each sowing way. The size of each plot is $30 \times 30 \mathrm{~m}$. Plot maintenance included seeding and pest control during the 
experimental period. Three key phenology phases were selected for irrigation: the re-greening stage (18 May 2013), the elongation stage (23 June 2013), and the heading stage (28 July 2013). Field capacity is the amount of soil moisture after excess water has drained away and the rate of downward movement has materially decreased. It was measured as the soil in three pots of each plot were saturated with water and excess water was drained out from the bottom holes of pots. Then the pots were covered with plastic sheet for two days to prevent evaporation and to allow downward redistribution of water. The TDR probes were then inserted vertically from the soil surface $(0-20 \mathrm{~cm})$ to determine field capacity. The irrigation schemes included four scenarios based on field capacity (27.29\%) and with no rain shelters as mentioned by Gong et al. [23]. Treatment 1 (T1) irrigated with enough water to reach $85 \%$ of field capacity. Treatment 2 (T2) was low deficit irrigation at $65 \%$ of field capacity. Treatment 3 (T3) was high deficit irrigation at $45 \%$ of field capacity. Treatment 4 (RF) was a rain-fed control with no irrigation. Each treatment included three replicated plots. A total of 48 plots were planted. Table 1 shows information on the irrigation schemes, survey time, and irrigation amounts during the different stages.

Table 1. Irrigation schemes and amounts at different stages.

\begin{tabular}{|c|c|c|c|c|c|c|}
\hline Irrigation Time & $\begin{array}{l}\text { Irrigation } \\
\text { Scheme * }\end{array}$ & $\begin{array}{l}\% \text { of Field } \\
\text { Capacity }\end{array}$ & $\begin{array}{c}\text { Irrigation } \\
\text { Amount }\left(\mathrm{m}^{3} / \mathrm{hm}^{2}\right)\end{array}$ & Survey Time & $\begin{array}{l}\text { Precipitation } \\
\left(\mathrm{m}^{3} / \mathrm{hm}^{2}\right)\end{array}$ & $\begin{array}{c}\text { Gross Irrigation } \\
\text { Amount }\left(\mathrm{m}^{3} / \mathrm{hm}^{2}\right)\end{array}$ \\
\hline \multirow{4}{*}{$\begin{array}{c}\text { Seeding } \\
\text { establishment } \\
\text { (18 May 2013) }\end{array}$} & $\mathrm{T} 1$ & 100 & 142.9 & \multirow{4}{*}{$\begin{array}{l}\text { Tillering stage } \\
\text { (4 June 2013) }\end{array}$} & 132.1 & 275 \\
\hline & $\mathrm{T} 2$ & 100 & 142.9 & & 132.1 & 275 \\
\hline & T3 & 100 & 142.9 & & 132.1 & 275 \\
\hline & RF & 100 & 142.9 & & 132.1 & 275 \\
\hline \multirow{4}{*}{$\begin{array}{l}\text { Tillering stage } \\
\text { (23 June 2013) }\end{array}$} & $\mathrm{T} 1$ & 85 & 528.5 & \multirow{4}{*}{$\begin{array}{l}\text { Heading and } \\
\text { flowering stage } \\
\text { (1 July 2013) }\end{array}$} & 591.8 & 1263.2 \\
\hline & $\mathrm{T} 2$ & 65 & 298.9 & & 591.8 & 1033.6 \\
\hline & T3 & 45 & 169.1 & & 591.8 & 903.8 \\
\hline & RF & 0 & 0 & & 591.8 & 734.7 \\
\hline \multirow{4}{*}{$\begin{array}{l}\text { Heading and } \\
\text { flowering stage } \\
\text { (28 July 2013) }\end{array}$} & $\mathrm{T} 1$ & 85 & 324 & \multirow{4}{*}{$\begin{array}{l}\text { Squaring stage } \\
\text { (9 August 2013) }\end{array}$} & 1358.9 & 1825.8 \\
\hline & $\mathrm{T} 2$ & 65 & 232.7 & & 1358.9 & 1734.5 \\
\hline & T3 & 45 & 141.5 & & 1358.9 & 1643.3 \\
\hline & RF & 0 & 0 & & 1358.9 & 1501.8 \\
\hline
\end{tabular}

* T1: treatment 1; T2: treatment 2; T3: treatment 3; RF: rain-fed control.

\subsection{Experimental Measurements}

Experimental measurements were carried out on 4th June, 1st July, 9th August, and 9th September in 2013. The examined indices included biomass of grasses, soil bulking density, and moisture content. Biomass was harvested in samples of $1 \times 1 \mathrm{~m}$. Soil bulking density was measured with cutting ring method. Each index was measured in one sample for each plot. Additionally, we took soil samples at $0-20 \mathrm{~cm}$ depth and grass samples from each plot. Then, forage nutrient elements-including the contents of crude protein $(\mathrm{CP})$, cellulose (CL), and crush ash (CA) - were tested in laboratory experiments (Table 2). The methods used to test $\mathrm{CP}, \mathrm{CL}$, and CA were Kjeldahl method, Weende analysis, and Burning method independently as mentioned in the reference [24]. Materials for measuring forage nutrient elements were collected in August when the plants reached the highest nutritional level. Each index was measured one time in each plot. Photosynthesis rate and transpiration rate of grass leaves were measured one time in each plot using the $\mathrm{Li}-6400$ portable photosynthesis system (Li-Cor, Inc., Lincoln, NE, USA) from 6:00 a.m. to 6:00 p.m. on a day during each stage for each treatment. A stationary meteorological station was fixed to provide long-term dynamic monitoring of local meteorological conditions. Four soil moisture meters were also placed in each treatment to monitor soil moisture and temperature during the study period. 
Table 2. ANOVA single factor comparison of forage yields, WUEI and WUEL in different stages and treatments ${ }^{1}$.

\begin{tabular}{|c|c|c|c|c|c|c|c|c|c|c|c|c|c|}
\hline \multirow{3}{*}{ Month } & \multirow{3}{*}{$\mathbf{T}$} & \multicolumn{3}{|c|}{$\begin{array}{l}\text { Medicago sativa } \mathrm{L} \text {. } \\
\text { by Single Sowing }\end{array}$} & \multicolumn{3}{|c|}{$\begin{array}{c}\text { Agropyron cristatum by Single } \\
\text { Sowing }\end{array}$} & \multicolumn{6}{|c|}{ Mixture Sowing } \\
\hline & & \multirow{2}{*}{ Yield } & \multirow{2}{*}{ WUEI } & \multirow{2}{*}{ WUEL } & \multirow{2}{*}{ Yield } & \multirow{2}{*}{ WUEI } & \multirow{2}{*}{ WUEL } & \multicolumn{2}{|c|}{ Medicago sativa $\mathrm{L}$. } & \multicolumn{2}{|c|}{ Agropyron cristatum } & \multirow{2}{*}{ Yield } & \multirow{2}{*}{ WUEL } \\
\hline & & & & & & & & Yield & WUEI & Yield & WUEI & & \\
\hline \multirow{4}{*}{ June } & $\mathrm{T} 1$ & $1522.58^{\text {abcde }}$ & $3.50^{\mathrm{ab}}$ & $75.92^{\mathrm{e}}$ & $599.74^{\mathrm{ab}}$ & $3.14^{\mathrm{ab}}$ & $30.22^{\mathrm{abc}}$ & $1409.10^{\mathrm{abc}}$ & $2.90^{\mathrm{ab}}$ & $233.10^{\mathrm{ab}}$ & $3.51^{\mathrm{abc}}$ & $1642.20^{\mathrm{abc}}$ & $82.84^{b}$ \\
\hline & $\mathrm{T} 2$ & $820.24^{\mathrm{abc}}$ & $3.70^{\mathrm{ab}}$ & $39.64^{\mathrm{bcd}}$ & $578.59^{\mathrm{ab}}$ & $2.45^{\mathrm{ab}}$ & $29.30^{\mathrm{abc}}$ & $459.82^{\mathrm{a}}$ & $2.45^{\mathrm{a}}$ & $142.49^{\mathrm{a}}$ & $2.74^{\mathrm{abc}}$ & $602.31^{\mathrm{a}}$ & $30.85^{\mathrm{a}}$ \\
\hline & $\mathrm{T} 3$ & $590.80^{\mathrm{abc}}$ & $2.51^{\mathrm{a}}$ & $26.77^{\mathrm{abc}}$ & $282.02^{\mathrm{a}}$ & $3.09^{\mathrm{ab}}$ & $14.10^{\mathrm{a}}$ & $540.63^{\mathrm{ab}}$ & $2.61^{\mathrm{a}}$ & $205.96^{\mathrm{ab}}$ & $6.32^{\mathrm{bc}}$ & $746.59^{\mathrm{ab}}$ & $37.17^{\mathrm{a}}$ \\
\hline & $\mathrm{RF}$ & $664.92^{\mathrm{abc}}$ & $4.74^{\mathrm{abc}}$ & $33.02^{\mathrm{abcd}}$ & $357.93^{\mathrm{a}}$ & $3.83^{\mathrm{abc}}$ & $17.91^{\mathrm{ab}}$ & $566.14^{\mathrm{ab}}$ & $3.39^{\mathrm{abc}}$ & $427.54^{\mathrm{ab}}$ & $3.73^{\mathrm{abc}}$ & $993.69^{a b c}$ & $49.90^{\mathrm{ab}}$ \\
\hline \multirow{4}{*}{ July } & $\mathrm{T} 1$ & $2259.68^{\text {def }}$ & $3.11^{\mathrm{ab}}$ & $23.68^{\mathrm{abc}}$ & $1756.77^{\text {bcde }}$ & $3.17^{\mathrm{ab}}$ & $18.39^{\mathrm{ab}}$ & $1700.53^{\mathrm{abcd}}$ & $2.08^{\mathrm{a}}$ & $382.90^{\mathrm{ab}}$ & $3.24^{\mathrm{abc}}$ & $2083.43^{\mathrm{abcd}}$ & $21.68^{a}$ \\
\hline & $\mathrm{T} 2$ & $1774.66^{\text {bcde }}$ & $2.27^{\mathrm{a}}$ & $24.49^{\mathrm{abc}}$ & 2168.29de & $2.30^{\mathrm{a}}$ & $29.84^{\mathrm{abc}}$ & $2090.82^{\mathrm{bcd}}$ & $1.93^{\mathrm{a}}$ & $316.94^{\mathrm{ab}}$ & $2.55^{\mathrm{ab}}$ & $2407.77^{\mathrm{cd}}$ & $33.28^{\mathrm{a}}$ \\
\hline & $\mathrm{T} 3$ & $1177.27^{\text {abcde }}$ & $2.03^{\mathrm{a}}$ & $21.42^{\mathrm{abc}}$ & $2123.64^{\text {de }}$ & $2.85^{\mathrm{ab}}$ & $35.69^{\mathrm{abc}}$ & $2077.76^{\mathrm{bcd}}$ & $2.23^{\mathrm{a}}$ & $473.67^{\mathrm{ab}}$ & $2.23^{\mathrm{a}}$ & $2551.42^{\mathrm{cd}}$ & $42.45^{\mathrm{ab}}$ \\
\hline & $\mathrm{RF}$ & $1167.68^{\mathrm{abcd}}$ & $2.62^{\mathrm{a}}$ & $27.00^{\mathrm{abc}}$ & $1307.06^{\mathrm{abcd}}$ & $3.12^{\mathrm{ab}}$ & $30.20^{\mathrm{abc}}$ & $1098.07^{\mathrm{abc}}$ & $2.64^{\mathrm{a}}$ & $1083.44^{\mathrm{b}}$ & $2.97^{a b c}$ & $2181.51^{\text {bcd }}$ & $50.50^{\mathrm{ab}}$ \\
\hline \multirow{4}{*}{ August } & $\mathrm{T} 1$ & $3178.16^{\mathrm{fg}}$ & $2.47^{\mathrm{a}}$ & $28.33^{\mathrm{abcd}}$ & $2096.58^{\text {de }}$ & $2.83^{\mathrm{ab}}$ & $18.70^{\mathrm{ab}}$ & $2403.02^{\mathrm{cd}}$ & $2.25^{\mathrm{a}}$ & $1073.18^{\mathrm{ab}}$ & $2.34^{\mathrm{ab}}$ & $3476.20^{\text {de }}$ & $31.13^{\mathrm{a}}$ \\
\hline & $\mathrm{T} 2$ & $2557.80^{\text {def }}$ & $2.31^{\mathrm{a}}$ & $24.81^{\mathrm{abc}}$ & $2050.07^{\text {cde }}$ & $2.29^{\mathrm{a}}$ & $19.92^{\mathrm{ab}}$ & $3168.20^{\text {de }}$ & $2.16^{\mathrm{a}}$ & $883.56^{\mathrm{ab}}$ & $1.99^{\mathrm{a}}$ & $4051.76^{\mathrm{d}}$ & $39.14^{\mathrm{a}}$ \\
\hline & $\mathrm{T} 3$ & $3972.73 \mathrm{~g}$ & $2.70^{\mathrm{a}}$ & $41.96^{\mathrm{cd}}$ & $2693.76^{\mathrm{e}}$ & $2.39^{a b}$ & $28.94^{\mathrm{abc}}$ & $3858.09^{\mathrm{e}}$ & $2.18^{\mathrm{a}}$ & $2184.78^{b}$ & $2.84^{\mathrm{abc}}$ & $6042.87^{\mathrm{e}}$ & $64.65^{\mathrm{ab}}$ \\
\hline & RF & $1978.20^{\text {cdef }}$ & $2.41^{\mathrm{a}}$ & $24.94^{\mathrm{abc}}$ & $2396.02^{\text {de }}$ & $2.67^{\mathrm{ab}}$ & $30.22^{\mathrm{abc}}$ & $1518.38^{\mathrm{abc}}$ & $1.78^{\mathrm{a}}$ & $2021.44^{c}$ & $1.63^{\mathrm{a}}$ & $3539.82^{\text {de }}$ & $44.63^{\mathrm{ab}}$ \\
\hline \multirow{4}{*}{ September } & $\mathrm{T} 1$ & $2642.89^{\text {ef }}$ & $4.97^{\mathrm{abc}}$ & $55.50^{\mathrm{d}}$ & $2994.60^{\mathrm{e}}$ & $4.55^{\mathrm{abc}}$ & $62.93^{\mathrm{d}}$ & $1845.51^{\mathrm{abcd}}$ & $2.61^{\mathrm{a}}$ & $252.62^{\mathrm{ab}}$ & $4.52^{\mathrm{abc}}$ & $2098.13^{\mathrm{abcd}}$ & $44.16^{\mathrm{ab}}$ \\
\hline & $\mathrm{T} 2$ & $662.51^{\mathrm{abc}}$ & $5.68^{\mathrm{bc}}$ & $13.93^{\mathrm{ab}}$ & $2247.31^{\mathrm{de}}$ & $4.81^{\mathrm{bc}}$ & $47.16^{\mathrm{cd}}$ & $626.27^{\mathrm{ab}}$ & $3.89^{\mathrm{abc}}$ & $475.53^{\mathrm{ab}}$ & $6.35^{\mathrm{bc}}$ & $1101.80^{\mathrm{abc}}$ & $29.76^{\mathrm{a}}$ \\
\hline & $\mathrm{T} 3$ & $324.80^{\mathrm{a}}$ & $4.86^{\mathrm{abc}}$ & $6.89^{\mathrm{a}}$ & $2027.82^{\text {cde }}$ & $4.60^{\mathrm{abc}}$ & $42.60^{\mathrm{bcd}}$ & $958.53^{\mathrm{abc}}$ & $5.13^{\mathrm{bc}}$ & $465.27^{\mathrm{ab}}$ & $3.36^{\mathrm{abc}}$ & $1423.80^{\mathrm{abc}}$ & $29.93^{\mathrm{a}}$ \\
\hline & $\mathrm{RF}$ & $359.96^{\mathrm{ab}}$ & $7.02^{\mathrm{C}}$ & $7.58^{\mathrm{a}}$ & $824.13^{\mathrm{abc}}$ & $6.06^{c}$ & $17.29^{\mathrm{ab}}$ & $624.71^{\mathrm{ab}}$ & $5.64^{\mathrm{c}}$ & $1066.33^{\mathrm{ab}}$ & $6.72^{c}$ & $1691.04^{\mathrm{abc}}$ & $35.56^{\mathrm{a}}$ \\
\hline \multicolumn{2}{|c|}{${ }^{2} \mathrm{M}(\mathrm{P})$} & ${ }^{4} \mathrm{D}(0.00)$ & ${ }^{4} \mathrm{D}(0.00)$ & ${ }^{4} \mathrm{D}(0.00)$ & ${ }^{4} \mathrm{D}(0.00)$ & ${ }^{4} \mathrm{D}(0.01)$ & ${ }^{4} \mathrm{D}(0.00)$ & ${ }^{4} \mathrm{D}(0.00)$ & ${ }^{4} \mathrm{D}(0.02)$ & ${ }^{4} \mathrm{D}(0.00)$ & ${ }^{4} \mathrm{D}(0.03)$ & ${ }^{4} \mathrm{D}(0.00)$ & $\operatorname{LSD}(0.21)$ \\
\hline \multicolumn{2}{|c|}{${ }^{3} \mathrm{~F}$} & 6.37 & 2.72 & 4.90 & 4.95 & 2.17 & 3.11 & 4.55 & 2.07 & 5.21 & 1.98 & 9.23 & 1.40 \\
\hline \multicolumn{2}{|c|}{${ }^{5} \mathrm{DF}$} & 47 & 47 & 47 & 47 & 47 & 47 & 47 & 47 & 47 & 47 & 47 & 47 \\
\hline
\end{tabular}

${ }^{1}$ The upper letters display whether the values significantly differ from others. They were calculated by ANOVA single factor comparison in SPSS 13.0. Each treatment in each stage

has three samples. In total, 48 samples were used for each ANOVA analysis. ${ }^{2}$ Method: testing method for multiple comparisons. The method was selected by the homogeneity test of variances, when $p \geq 0.05$, LSD was selected, or else DUNCAN was selected. ${ }^{3} \mathrm{~F}$ : F test value. ${ }^{4}$ D: DUNCAN's multiple range test; ${ }^{5} \mathrm{DF}$ : the number of degree of freedom. 


\subsection{Data Analysis}

WUE was calculated with two indicators

$$
\text { WUEI }=P_{n} \div T_{r}
$$

where in a given growth stage, WUEI is the instantaneous WUE at the leaf scale, the unit is $\mathrm{mol} \cdot \mathrm{CO}_{2} / \mathrm{mmol} \cdot \mathrm{H}_{2} \mathrm{O} ; P_{n}$ is the photosynthetic rate $\left(\mu \mathrm{mol} \cdot \mathrm{CO}_{2} \cdot \mathrm{m}^{-2} \cdot \mathrm{s}^{-1}\right)$, and $T_{r}$ is the transpiration rate $\left(\mathrm{mmol} \cdot \mathrm{m}^{-2} \cdot \mathrm{s}^{-1}\right)$.

$$
W U E L=W_{d m} \div E T
$$

where in a given growth stage, WUEL is the long-term WUE at population and community scales, the unit is $\mathrm{kg} / \mathrm{mm} \cdot \mathrm{hm}^{2} ; W_{d m}$ is the amount of dry matter of the forage per unit $\left(\mathrm{kg} / \mathrm{hm}{ }^{2}\right)$, ET is the evapotranspiration of the forage $(\mathrm{mm})$. ET is calculated as

$$
E T=P+I \pm v S
$$

where in a given growth stage, $P$ is the precipitation amount $(\mathrm{mm}), I$ is the irrigation amount $(\mathrm{mm}), v S$ is the difference in soil water content between the early and late growth stages $(\mathrm{mm})$.

Different multivariate analyses were also performed (ANOVA single factor comparison) to compare the effects of irrigation schemes and planting treatments on forage yield, WUEI, WUEL, and nutrient elements. The differences were considered significant at $p<0.05$. All statistical analyses were performed in version 13.0 of SPSS software (SPSS Inc., Chicago, IL, USA).

\section{Results}

The results of ANOVA single factor comparison of forage yields, WUEI, and WUEL in different stages and treatments were shown in Table 2. It can be inferred from Table 3 that, compared to other sowing methods and indices, forage yields under the single sowing of $M$. sativa displayed bigger differences by stages and treatment. They were classified into seven groups. WUEL under mixture sowing exhibited smaller differences by stages and treatments with only two groups distinguished. 
Table 3. ANOVA single factor comparison ${ }^{1}$ of contents of forage nutrients in different sowing treatments.

\begin{tabular}{|c|c|c|c|c|c|c|c|c|c|c|c|c|}
\hline \multirow{2}{*}{$\mathrm{T}$} & \multicolumn{3}{|c|}{ Contents in MSS $^{2}$} & \multicolumn{3}{|c|}{ Contents in MSM $^{2}$} & \multicolumn{3}{|c|}{ Contents in ACS ${ }^{2}$} & \multicolumn{3}{|c|}{ Contents in $\mathrm{ACM}^{2}$} \\
\hline & $\mathrm{CP}$ & CA & CL & CP & $\mathrm{CA}$ & CL & CP & CA & CL & CP & CA & CL \\
\hline $\mathrm{T} 1$ & $14.15^{\mathrm{b}}$ & $10.81^{\mathrm{b}}$ & $32.85^{\mathrm{a}}$ & $8.58^{\mathrm{a}}$ & $10.49^{a}$ & $30.07^{\mathrm{b}}$ & $8.08^{\mathrm{a}}$ & $7.44^{\mathrm{ab}}$ & $31.15^{b}$ & $8.02^{\mathrm{a}}$ & $6.46^{\mathrm{ab}}$ & $32.19^{\mathrm{b}}$ \\
\hline $\mathrm{T} 2$ & $8.08^{\mathrm{a}}$ & $7.44^{\mathrm{a}}$ & $31.15^{\mathrm{a}}$ & $11.74^{\mathrm{b}}$ & $12.97^{\mathrm{b}}$ & $29.14^{\mathrm{b}}$ & $12.22^{\mathrm{a}}$ & $9.29^{b}$ & $26.45^{\mathrm{a}}$ & $8.27^{\mathrm{a}}$ & $6.84^{\mathrm{b}}$ & $32.85^{b}$ \\
\hline T3 & $13.99^{\mathrm{b}}$ & $10.59^{\mathrm{b}}$ & $30.05^{\mathrm{a}}$ & $15.19^{c}$ & $15.83^{c}$ & $28.10^{\mathrm{ab}}$ & $8.08^{\mathrm{a}}$ & $6.58^{\mathrm{ab}}$ & $31.01^{\mathrm{b}}$ & $5.85^{\mathrm{a}}$ & $6.33^{\mathrm{ab}}$ & $25.90^{\mathrm{a}}$ \\
\hline RF & $14.84^{\mathrm{b}}$ & $9.52^{\mathrm{ab}}$ & $27.53^{\mathrm{a}}$ & $15.17^{c}$ & $12.69^{\mathrm{b}}$ & $23.16^{a}$ & $8.40^{\mathrm{a}}$ & $4.95^{\mathrm{a}}$ & $27.04^{\mathrm{ab}}$ & $8.32^{\mathrm{a}}$ & $5.51^{\mathrm{a}}$ & $24.27^{\mathrm{a}}$ \\
\hline${ }^{1} \mathrm{M}(\mathrm{P})$ & ${ }^{4} \mathrm{D} 0.042$ & ${ }^{4} \mathrm{D} 0.048$ & LSD 0.216 & ${ }^{4} \mathrm{D} 0.001$ & ${ }^{4} \mathrm{D} 0.005$ & LSD 0.102 & LSD 0.207 & LSD 0.097 & LSD 0.055 & LSD 0.615 & LSD 0.070 & ${ }^{4} \mathrm{D} 0.005$ \\
\hline${ }^{3} \mathrm{~F}$ & 4.41 & 4.15 & 1.61 & 22.53 & 10.88 & 3.03 & 1.97 & 3.11 & 4.16 & 0.64 & 3.69 & 11.15 \\
\hline${ }^{5} \mathrm{DF}$ & 11 & 11 & 11 & 11 & 11 & 11 & 11 & 11 & 11 & 11 & 11 & 11 \\
\hline
\end{tabular}

${ }^{1}$ Method: testing method for multiple comparisons. Each treatment has three samples. In total, 12 samples were used for each ANOVA analysis. The method was selected by the homogeneity test of variances, when $p \geq 0.05$, LSD was selected, or else DUNCAN was selected; ${ }^{2}$ MSS: $M$. sativa by single sowing; MSM: M. sativa by mixture sowing; ACS: A. cristatum

by single sowing; ACM: A cristatum by mixture sowing; ${ }^{3} \mathrm{~F}$ : F test value; ${ }^{4} \mathrm{D}$ : DUNCAN's multiple test. The parameters with the same letter are not significantly different at $p=0.05$ according to the selected method; ${ }^{5} \mathrm{DF}$ : the number of degree of freedom. 


\subsection{Impact of Irrigation Schemes on Forage Yield}

Table 2 and Figure 1 show that for both species and sowing ways, forage yields in August-especially under T3 treatment-were significantly higher than those in other stages. The values decreased in September. Furthermore, in the stages except August, T1 usually obtained insignificantly higher forage yields than most other treatments. For all stages, the irrigation treatments always have slightly higher forage yields than RF.
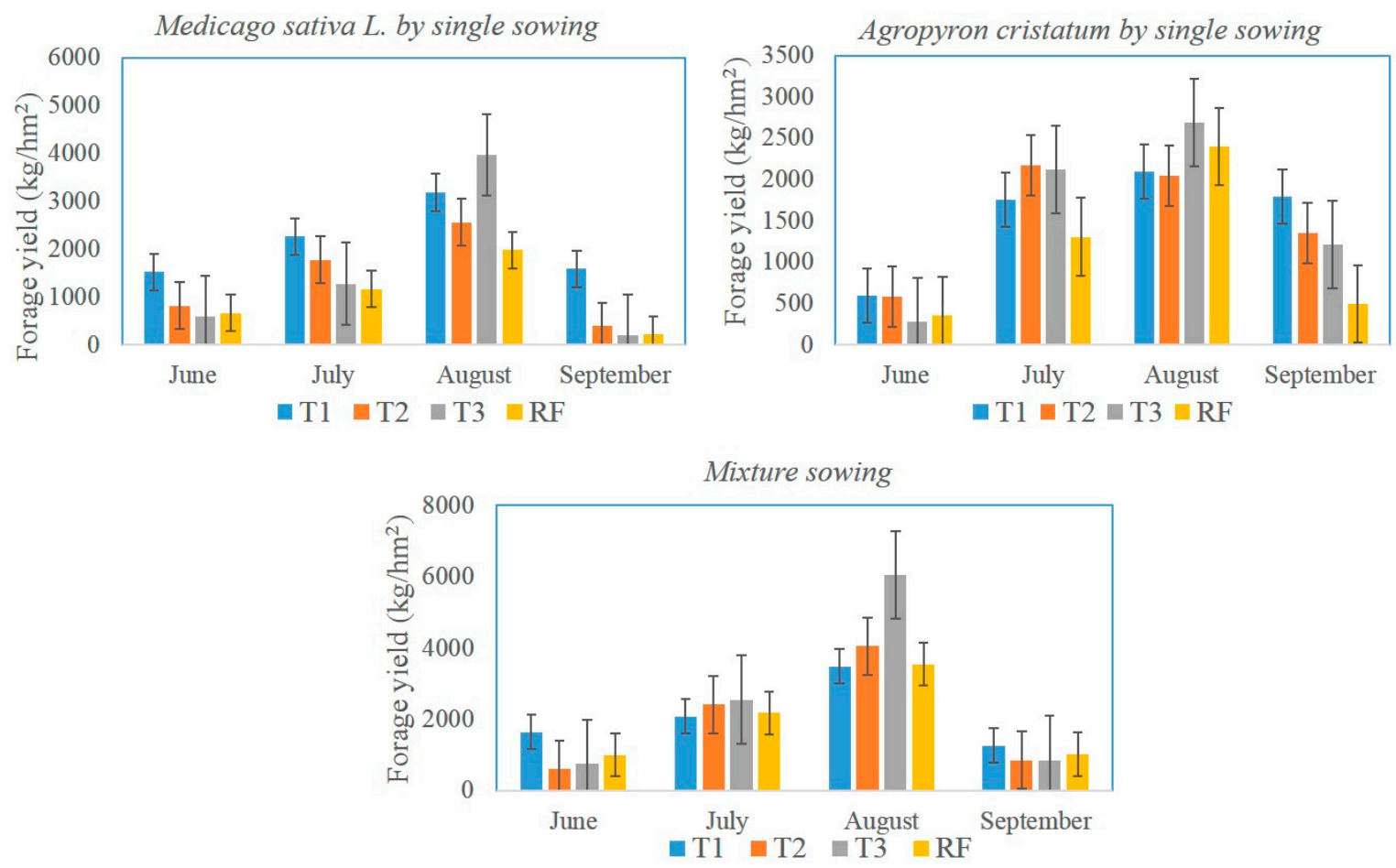

Figure 1. Mean values (with error bars) of forage yield in different sowing treatments (the colors of the bars represent different treatments, the grey lines above the bars mean the error bars).

\subsection{Impact of Irrigation Schemes on WUE}

\subsubsection{WUEI}

Table 2 and Figure 2 show that comparing to other stages and treatments, WUEIs were significantly higher in September especially under RF for both species and sowing ways. For M. sativa of both sowing ways, WUEIs were a little low in July and August under the four treatments. For A. cristatum of both sowing ways, WUEIs were a little low in August especially under T2. 


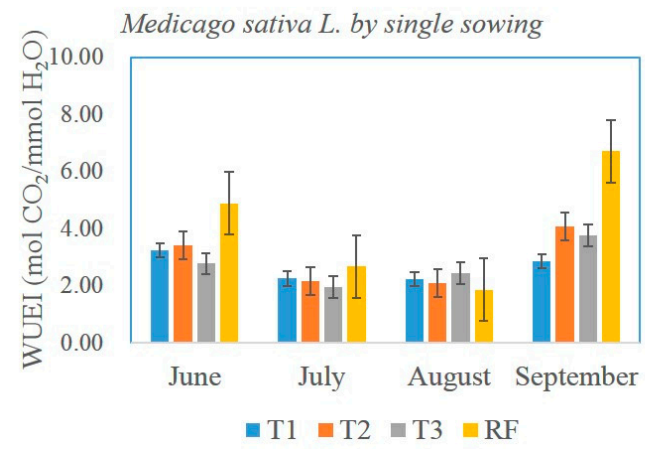

Medicago sativa L. by mixture sowing

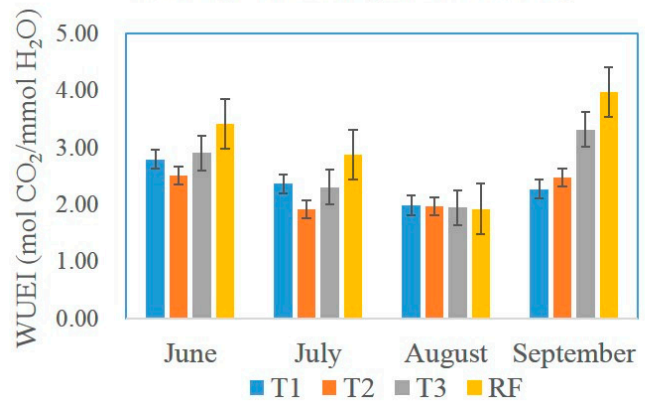

Agropyron cristatum by single sowing

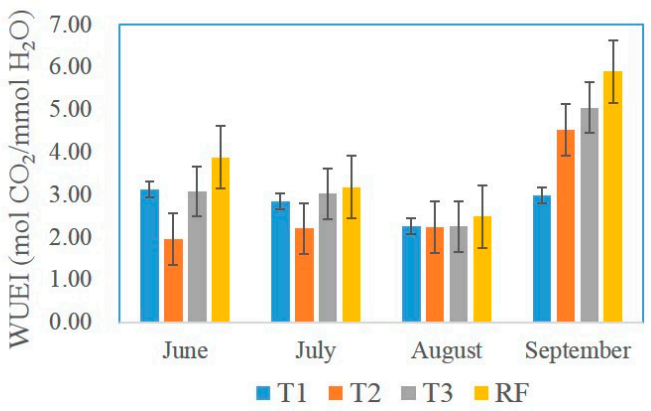

Agropyron cristatum by mixture sowing

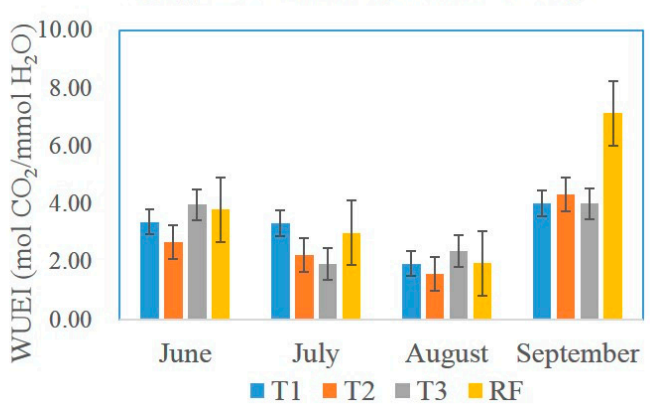

Figure 2. Mean values (with error bars) of WUEI in different treatments by sowing treatments (the colors of the bars represent different treatments, the grey lines above the bars mean the error bars).

\subsubsection{WUEL}

Table 2 and Figure 3 show that comparing to most other stages and sowing ways, WUELs were significantly higher in June and September under T1 for the single sowing of $M$. sativa and the mixture sowing, and in September under T1 for the single sowing of A. cristatum. The differences of WUELs in most other stages and sowing methods were not significant, since they belong to the same groups.

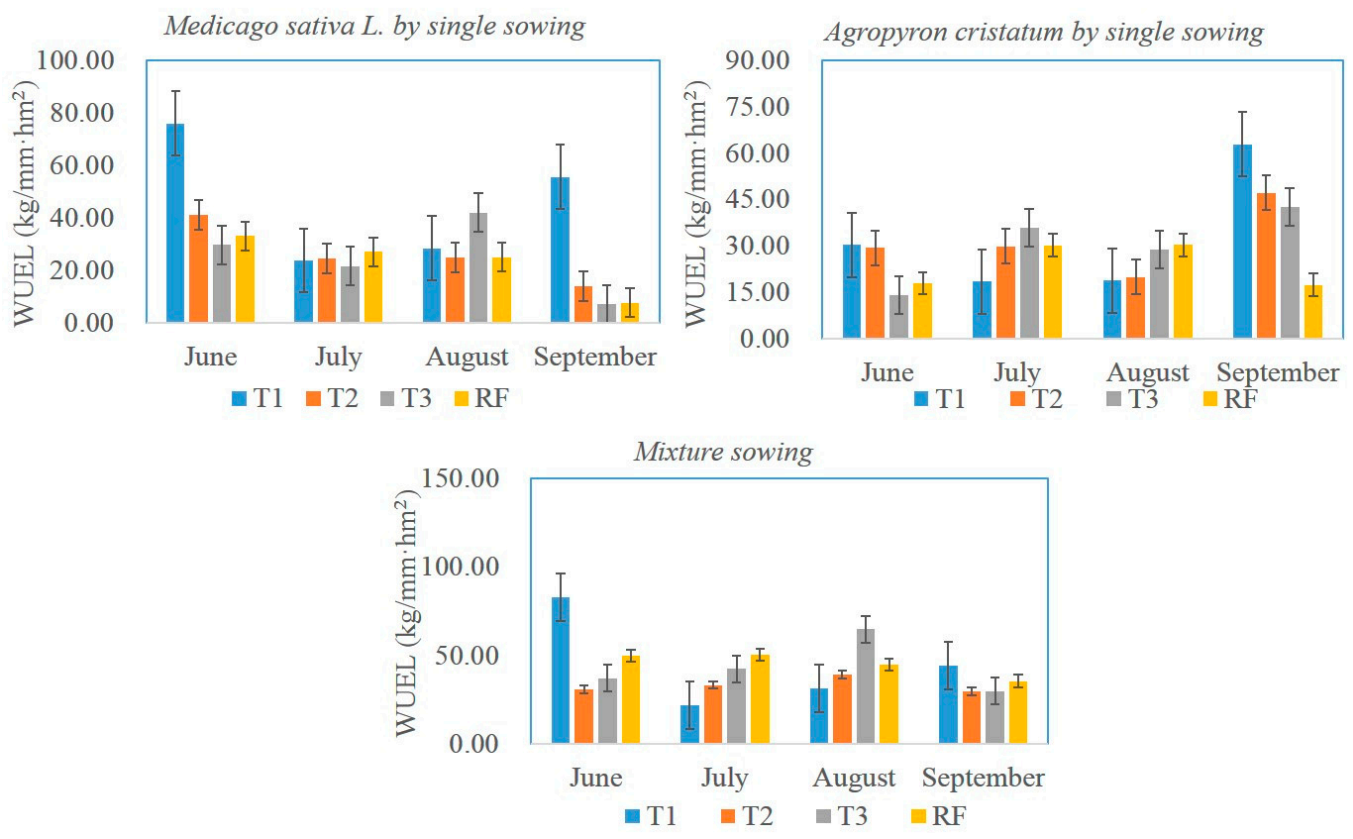

Figure 3. Mean values with (error bars) of WUEL in different sowing treatments (the colors of the bars represent different treatments, the grey lines above the bars mean the error bars). 


\subsection{Impact of Irrigation on Forage Nutrient Elements}

Table 3 shows the contents of forage nutrient elements in different sowing treatments. A forage with high nutritional level usually has high crude protein and low cellulose contents and ash content. Compared to RF, T1 can significantly increase the contents of CL in both species by mixture sowing, but decrease the contents of $\mathrm{CP}$ and $\mathrm{CA}$ in $\mathrm{M}$. sativa by mixture sowing. T2 can significantly increase the contents of $C L$ in both species by mixture sowing method and the contents of $C A$ in A. cristatum by both sowing methods, but decrease the contents of CP in $M$. sativa by both sowing methods. Compared to T1 and T2, T3 and RF have significantly higher contents of CP in M. sativa by both sowing methods and lower contents of $\mathrm{CL}$ in both species by mixture sowing. RF also has insignificantly lower contents of CA in both species and sowing ways. The other comparisons were also insignificant. Thus, T3 and RF are preferable to enhance nutritional levels of both species and sowing ways.

\section{Discussions and Conclusions}

\subsection{Impact of Irrigation on Forage Yield and Nutritional Level}

Plant responses to irrigation strategies were based on the phenological stage when it was applied. Several studies have documented that water scarcity can reduce the final plant load during flowering and the initial stage of plant growth; and water scarcity negatively affected plant production during the tilling stage $[11,25,26]$. Our results also indicated that compared to the rain-fed control treatment, irrigation can increase forage yields of $M$. sativa and A. cristatum in most stages and by both sowing techniques. Since the highest yields appeared in August under all treatments and sowing techniques, we concluded that August is the optimal period to harvest the two species.

In order to enhance forage yield and save water through irrigation in arid areas with extreme water shortage, it is assumed that deficit irrigation is more effective than irrigating with sufficient water (T1). Our results also indicated that heavy deficit irrigation (T3) has the maximum potential to increase forage yields of both species in the squaring stage. A slight decrease of yield in the earlier stages could be compensated in the later stages when applying deficit irrigation, as was mentioned in other studies [27]. Heavy deficit irrigation and rain-fed control were also effective ways to improve forage nutritional levels of both species under two sowing methods.

\subsection{Impact of Water Scarcity on Water-Use Efficiency}

Water-use efficiency (WUE) is an indicator for assessing the validity of deficit irrigation on yield increase [28]. Our results indicated that the impacts of irrigation on WUE differed between WUEI and WUEL. Rain-fed controls were preferable for increasing WUEI for both species in September. This may be due to the adaptability of both forage species to water scarcity. In the study area, precipitation is always low in September, providing an insufficient water supply. When affected by water availability, plants tend to accumulate ingredients, such as soluble sugar and proline, to decrease in vivo osmotic pressure and sustain water uptake from outside [28]. They also close stomas to reduce transpiration under water pressure. Thus, no irrigation water can maintain high WUEI for M. sativa and A. cristatum in most stages and under both sowing techniques. Previous studies have also verified that WUEI can be increased under water scarcity because most of the applied water remains in the root zone instead of being depleted by ET [29,30]. However, in June and September, only irrigating to near field capacity (T1) can increase the WUEL of both species. The reason may be that the strong evapotranspiration that may consume a large amount of water in the plants in the study area.

\subsection{Optimum Schedule to Increase Forage Quality and Save Water}

In summary, deficit irrigation and even no-irrigation are effective water management techniques to both save water and increase forage-quality related factors, including forage yield, nutritional levels, and WUEI for the two species in most sowing ways. This has also been validated by previous studies [19]. Because of the sensitivity and resistance to water scarcity in different stages, the forages 
displayed different adaptive strategies to water availability, which were characterized by the impacts of irrigation schemes on forage qualities. The optimum schedule is irrigating to near field capacity in June when the forage is sensitive to water scarcity and applying deficit irrigation in July and August when the forage species were more resistant to water scarcity [31,32]. For future research, we suggest focusing on optimizing irrigation amounts and timing and identifying suitable species mixtures. Reasons as to why heavy deficit irrigation could produce more biomass than T1 and T2 should also be discussed by analyzing the physiological and biochemical response of plants to irrigation schemes. More specific guidelines will help growers to maximize water use efficiency in grassland production in arid regions.

Acknowledgments: This study received support from the National Basic Research Program of China (2016YFC0500502), and the project supported by State Key Laboratory of Earth Surface Processes and Resources Ecology (2017-FX-01(1)). The funds cover the costs to publish in open access.

Author Contributions: Yuhong Tian conceived and designed the experiments; Yiqing Liu performed the experiments; Jianjun Jin analyzed the data; Yuhong Tian and Yiqing Liu wrote the paper.

Conflicts of Interest: The authors declare no conflict of interest. The founding sponsors had no role in the design of the study; in the collection, analyses, or interpretation of data; in the writing of the manuscript, or in the decision to publish the results.

\section{References}

1. Wang, W.; Fang, J.Y. Soil respiration and human effects on global grasslands. Glob. Planet. Chang. 2009, 67, 20-28. [CrossRef]

2. Zhang, X.S. China must take the road of the development of artificial grass and grassland agriculture. Impact Sci. Soc. 2010, 3, 18-21. (In Chinese)

3. Xu, K.K.; Wang, H.; Li, X.B.; Chi, D.K.; Yu, F. Identifying areas suitable for cultivation of Medicago sativa L. in a typical steppe of Inner Mongolia. Environ. Earth Sci. 2016, 75, 341. [CrossRef]

4. Ates, S.; Tongel, M.O.; Moot, D.J. Annual herbage production increased when sub clover overdrilled into grass-dominant dryland pastures. Proc. N. Z. Grassl. Assoc. 2012, 72, 3-10.

5. Ren, X.Y.; Xu, Z.W.; Isbell, F.; Huang, J.H.; Han, X.G.; Wan, S.Q.; Chen, S.P.; Wang, R.Z.; Zeng, D.H.; Jiang, Y. Exacerbated nitrogen limitation ends transient stimulation of grassland productivity by increased precipitation. Ecol. Monogr. 2017, 87, 457-469. [CrossRef]

6. Jensen, K.B.; Asey, K.H.; Waldron, B.L. Dry matter production of orchardgrass and perennial ryegrass at five irrigation levels. Crop Sci. 2001, 41, 479-487. [CrossRef]

7. Dantas, G.D.; De Faria, R.T.; Dos Santos, G.D.; Dalri, A.B.; Palaretti, L.F. Herbage yield and quality of irrigated Brachiaria in Autumn and Winter. Eng. Agricola 2016, 36, 469-481. [CrossRef]

8. Sanches, A.C.; Gomes, E.P.; Rickli, M.E.; Friske, E.; Fasolin, L.P. Productivity and nutritive value of Tifton 85 in summer, with and without irrigation under different Nitrogen doses. Eng. Agricola 2017, 27, 246-256. [CrossRef]

9. Isik, S.; Ates, S.; Gunes, A.; Aktas, A.H.; Keles, G. Effect of deficit irrigation on dry matter and sheep production from permanent sown pastures. In New Approaches for Grassland Research in a Context of Climate and Socio-Economic Changes; Acar, Z., López-Francos, A., Porqueddu, C., Eds.; Ciheam: Zaragoza, Spain, 2012; pp. 327-331.

10. Zhang, X.; Pei, D.; Li, Z.; Wang, Y. Management of supplemental irrigation of winter wheat for maximum profit. Deficit irrigation practices. FAO Water Rep. 2002, 22, 57-66.

11. English, M.J.; Musich, J.T.; Murty, V.V.N. Deficit irrigation. In Management of Farm Irrigation Systems; Hoffman, G.J., Howell, T.A., Solomon, K.H., Eds.; ASAE: St. Joseph, MI, USA, 1990.

12. Zheng, Y.; Zhang, Y.; $\mathrm{Wu}$, J. Yield and quality of Moringa oleifera under different planting densities and cutting heights in southwest China. Ind. Crops Prod. 2016, 91, 88-96. [CrossRef]

13. Antoniewicz, A.M.; Kowalczyk, J.; Kanski, J.; Gorska-Matusiak, Z.; Nalepka, M. Rumen degradability of rude protein of dried grass and Lucerne forage measured by in sacco incubation and predicted by near infrared spectroscopy. Anim. Feed Sci. Technol. 1995, 54, 203-216. [CrossRef]

14. Colmenero, J.J.O.; Broderick, G.A. Effect of dietary crude protein concentration on milk production and Nitrogen utilization in Lactating dairy cows. J. Dairy Sci. 2006, 89, 1704-1712. [CrossRef] 
15. Allinson, D.W.; Osbourn, D.F. The cellulose-lignin complex in forage and its relationship to forage nutritive value. J. Agric. Sci. 1970, 74, 23-26. [CrossRef]

16. Hunt, L.A. Ash and energy content of material from seven forage grasses. Crop Sci. 1966, 6, 507-509. [CrossRef]

17. Cantore, V.; Lechkar, O.; Karabulut, E.; Sellami, M.H.; Albrizio, R.; Boari, F.; Stellacci, A.M.; Todorovic, M. Combined effect of deficit irrigation and strobilurin application on yield, fruit quality and water use efficiency of "cherry" tomato (Solanum lycopersicum L.). Agric. Water Manag. 2016, 167, 53-61. [CrossRef]

18. Dourte, D.; Bartel, R.L.; George, S.; Marois, J.J.; Wright, D.L. A sod-based cropping system for irrigation reductions. Renew. Agric. Food Syst. 2016, 31, 485-494. [CrossRef]

19. Kifle, M.; Gebretsadikan, T.G. Yield and water use efficiency of furrow irrigated potato under regulated deficit irrigation, Astibi-Wemberta, North Ethiopia. Agric. Water Manag. 2016, 170, 133-139. [CrossRef]

20. Lu, S.; Zhang, X.; Liang, P. Influence of drip irrigation by reclaimed water on the dynamic change of the nitrogen element in soil and tomato yield and quality. J. Clean. Prod. 2016, 139, 561-566. [CrossRef]

21. Audrey, A.; Humbert, J.Y.; Arlettza, R. Functional response of leaf- and planthoppers to modern fertilization and irrigation of hay meadows. Basic Appl. Ecol. 2016, 17, 627-637.

22. Niu, J. Relationship between main vegetation types and climatic factors in Inner Mongolia. Chin. J. Appl. Ecol. 2000, 11, 47-52. (In Chinese)

23. Gong, J.R.; Xu, S.; Wang, Y.H.; Luo, Q.P.; Liu, M.; Zhang, W. Effect of irrigation on the soil respiration of constructed grasslands in Inner Mongolia, China. Plant Soil 2015, 395, 159-172. [CrossRef]

24. Yang, S. Analysis of Feed and Feed Quality Detection Technology; Beijing Agricultural University Press: Beijing, China, 1993; pp. 4-5. (In Chinese)

25. Ballester, C.; Castel, J.; Abd El-Mageed, T.A.; Castel, J.R.; Intrigliolo, D.S. Long-term response of 'Clementina de Nules' citrus trees to summer regulated deficit irrigation. Agric. Water Manag. 2014, 138, 78-84. [CrossRef]

26. Panigrahi, P.; Sharma, R.K.; Hasan, M.; Parihar, S.S. Deficit irrigation scheduling and yield prediction of 'Kinnow' mandarin (Citrus reticulata Blanco) in a semiarid region. Agric. Water Manag. 2014, 140, 48-60. [CrossRef]

27. English, M.J.; Solomon, K.H.; Hoffman, G.J. A paradigm shift in irrigation management. J. Irrig. Drain. Eng. 2002, 128, 267-277. [CrossRef]

28. Zhu, X.; Zhang, C. Main functional proteins in plant responses to water stress. Acta Bot. Boreal. Occident. Sin. 2002, 23, 503-508.

29. Tari, A.F. The effects of different deficit irrigation strategies on yield, quality, and water-use efficiencies of wheat under semi-arid conditions. Agric. Water Manag. 2016, 167, 1-10. [CrossRef]

30. Fereres, E.; Soriano, M.A. Deficit irrigation for reducing agricultural water use. Special issue on integrated approaches to sustain and improve plant production under drought stress. J. Exp. Bot. 2007, 58, 147-159, Special issue. [CrossRef] [PubMed]

31. Blum, F.A. Effective use of water (EUW) and not water-use efficiency (WUE) is the target of crop yield improvement under drought stress. Field Crops Res. 2009, 112, 119-123. [CrossRef]

32. Geerts, S.; Raes, D.; Gracia, M.; Miranda, R.; Cusicanqui, J.A.; Taboada, C.; Mendoza, J.; Huanca, R.; Mamani, A.; Condori, O.; et al. Simulating yield response of Quinoa to water availability with AquaCrop. Agron. J. 2009, 101, 499-508. [CrossRef]

(C) 2017 by the authors. Licensee MDPI, Basel, Switzerland. This article is an open access article distributed under the terms and conditions of the Creative Commons Attribution (CC BY) license (http://creativecommons.org/licenses/by/4.0/). 